\title{
WHY MOST AGRICULTURAL TERRACES IN STEEP SLOPES IN SEMIARID SE SPAIN REMAIN WELL PRESERVED SINCE THEIR ABANDONMENT 50 YEARS AGO?
}

\author{
A. Solé-Benet ${ }^{1 *}$, R. LÁZaro ${ }^{1}$, F. Domingo ${ }^{1,3}$, Y. CAntón ${ }^{2} \&$ J. Puigdefábregas $^{1}$ \\ 1 Estación Experimental de Zonas \\ Áridas, CSIC, carretera de Sacramento s/n, La Cañada de San Urbano, 04120 Almería, Spain \\ 2 Depto. Edafología y Química Agrícola, Escuela Politécnica Superior, Universidad de Almería, \\ carretera de Sacramento s/ $n$, La Cañada de San Urbano, 04120 Almería, Spain \\ 3 Dpto. Biología Vegetal y Ecología, Escuela Politécnica Superior, Universidad de Almería, \\ carretera de Sacramento s/n, La Cañada de San Urbano, 04120 Almería, Spain \\ e-mail: albert@eeza.csic.es
}

\begin{abstract}
A large part of the agricultural terraces in mountain environments are abandoned, like those from the Filabres range in Almeria, SE Spain. While many of such terraces show signs of soil erosion (wall disruptions, surface crusts, pipes and gullies), others in steep slopes remain well preserved after 50 years since their abandonment and still seem to play an active role against soil erosion. In order to know both magnitude of soil erosion and controlling factors in different types of abandoned terraces, a rainfall simulation campaign with a portable sprinkler was carried out in 45 representative microsites. Runoff, derived-infiltration and sediment production were measured and their relationships to basic soil parameters (particle size distribution, $p H, E C$, organic matter content, aggregate stability), geomorphic position, and ground cover, were examined.

Under the average applied rainfall intensity $(48 \mathrm{~mm} / \mathrm{h}$, which represents a precipitation with a return period of 5 years in the area), narrow bench terraces from steep hillslopes, have larger infiltration values and deliver less sediments than large bank terraces in alluvial plains. The presence of stony pavement sieving crusts on narrow-bench terraces and also on un-terraced alluvial fans, play an essential armouring effect against soil erosion while favouring water infiltration. Considerations are made about the evolution of the different types of traditional terraces in the area under both past agricultural and present abandoned status, and also about possible uses under a sustainable land management policy.
\end{abstract}

Keywords: Rainfall simulation; infiltration; runoff, erosion; surface crust. 
A. SOLÉ-BENET, R. LÁZARO, F. DOMINGO, Y. CANTÓN \& J. PUIGDEFÁBREGAS

RESUMEN.- Una gran parte de las terrazas agrícolas en zonas de montaña están abandonadas, como las de la Sierra de los Filabres en Almería, SE de España. Si bien muchas de dichas terrazas muestran señales de erosión hídrica (destrucción de muros, encostramiento superficial, piping y cárcavas), otras en laderas con pendientes acusadas siguen bien conservadas tras 50 años de abandono y da la impresión de que todavía juegan un papel activo contra la erosión del suelo. Con la finalidad de conocer tanto la magnitud de la erosión como sus factores causantes en distintos tipos de terrazas abandonadas, se llevó a cabo una campaña de simulación de lluvia con un aspersor portátil en 45 sitios representativos de la vertiente Sur de la Sierra de los Filabres. En cada simulación se midió la escorrentía y la producción de sedimentos, se calculó la infiltración y se determinaron las relaciones de dichos parámetros con los del suelo (granulometría, $p H, C E$, materia orgánica, $\mathrm{CaCO}_{3}$ y estabilidad de los agregados), con su posición geomorfológica y con la cubierta.

En las condiciones de precipitación utilizadas $(48 \mathrm{~mm} / \mathrm{h}$, que representan un periodo de retorno de 5 años en la zona), las terrazas de banco estrecho en laderas con fuerte pendiente presentan mayores tasas de infiltración y proporcionan menos sedimentos que las terrazas de banco amplio de las llanuras aluviales. La presencia generalizada de costras filtrantes con pavimento de gravas en las terrazas de banco estrechas, y también en los abanicos aluviales no aterrazados, favorece la infiltración y juega un papel protector contra la erosión hídrica. Se especula sobre la evolución de los distintos tipos de terraza de la zona bajo las anteriores condiciones agrícolas y en su estado de abandono actual y también acerca de los posibles usos en un contexto de manejo sostenible del territorio.

Palabras clave: Simulación de lluvia; infiltración; escorrentía; erosión; costra superficial.

\section{Introduction}

In many parts of semiarid mountains of SE Spain, the landscape is partly covered by many types of agricultural terraces. The southern versant of the Filabres range, in Almeria province, is one of such areas. Those terraces associated to ephemeral rivers are known to be many centuries old (GARCIA LATORRE \& GARCIA LATORRE, 2007) and were irrigated, and sometimes still are, by diversion channels (boqueras) from the main one or from adjacent sloping contributing areas, known as jessour in the Maghreb (BALLAIS, 1990; SCHIETTECATTE et al., 2005). Most of them were abandoned in the early sixties of the $20^{\text {th }}$ century though they are cultivated every few years for cereals (mainly barley) essentially to maintain a hunting population of partridge (Perdix perdix). When not cultivated, the terraces show a quite dense cover of the sparse bush Retama sphaerocarpa. Those associated to steep slopes are narrow bench terraces with stony walls and were built in the second half 
of the $19^{\text {th }}$ century coinciding with a rural population increase due to boosted mining activity and were abandoned some decades before the ones at the valley bottom (GARCIA LATORRE \& GARCIA LATORRE, 2007). These terraces have relatively narrow flat banks and more or less steep contributing areas which were kept bare to favour runoff which infiltrated downslope in the banks. Since the abandonment, slopes have been colonized by many shrubs (Anthyllis cytisoides, Ramus lyciodes, Cystus albidus) while the banks are covered mostly by annual plants (mostly Stipa capensis).

The abandonment of agricultural terraces is known to have important geomorphological impacts and today many abandoned terraces show signs of soil erosion (wall disruption, surface crusting, piping, rills and gullies), as described in many places in Spain (ARNAEZ \& ORTIGOSA, 1993; CAMMERAAT, 2004; FAULKNER et al., 2003; GARCIA-RUIZ, 1988; GARCIA-RUIZ \& LASANTA, 1990; LASANTA et al., 2001; LESSCHEN et al., 2008; PALLARÉS, 1994 among many others) and worldwide (e.g. FANG et al., 1981; GROVE \& RACHMAN, 2001; INBAR et al., 2000; KOULOURI \& GIOURGA, 2007; INBAR \& LLERENA, 2000; LLERENA et al., 2004). However, the abandoned narrow-bench terraces over mica schist slopes in SE Spain show a high degree of conservation even in those which walls seem to have been poorly built as irregular piles of stones of different sizes and shapes.

Though many facts are known from the literature about abandoned terraces (e.g. LLERENA et al., 2004; PALLARÉS, 1994; SALAS, 2004), in the context of a mountain semiarid landscape in SE Spain several questions remain unanswered. Why narrow- bench terraces on steep slopes show such a high degree of conservation with regards to other flat terraces in alluvial plains which suffer piping and gully erosion? What is the magnitude of soil erosion in the different types of terraces? Is this magnitude similar to abandoned terraces from different environments? What is the hydrological behaviour of the different types of abandoned terraces? Do the soils from the abandoned terraces behave differently than those non-terraced from other geomorphic surfaces (e.g. slopes, alluvial plains)?

Trying to respond to the former questions constitutes the aim of this paper: to know how the different terraces in different landscape positions contribute to the water and sediment budgets of the basin. The following specific objectives were sought: a) to know runoff and derived-infiltration values from the different types of terraces compared to other non-terraced slopes; b) to know the amount of sediments produced by runoff in such different terraces and non-terraced surfaces; c) to know the relationships of runoff, infiltration and sediment yield with essential landform and soil parameters. 
As it is well known that rainfall simulation has been largely used to ascertain the hydrological behaviour of soils in terms of runoff, infiltration and erosion in different landforms (SCOGING, 1982, BOUYER-BOWE, 1989; CERDÀ, 1994; SOLÉ-BENET et al, 1997; CAMMERAAT et al., 2004; among many others), this technique was used in a field campaign to try to respond to the former questions.

Data from the hydrological behaviour of soils from different abandoned terraces will be related to landform attributes like morphology, essential soil properties, ground cover, and the relationships among them.

\section{Site Information}

\subsection{General features}

Rambla Honda, locally known as rambla del Saltador, in Almeria province (SE Spain), is a $32 \mathrm{~km}^{2}$ watershed, N-S oriented, in the southern versant of the Filabres range (Fig.1A), from $500 \mathrm{~m}$ to $1700 \mathrm{~m}$ a.s.l., where mica schist is the dominant lithology.

The incision of Rambla Honda in the middle to lower part of the Filabres range, has formed three main units across the valley: a) steep rocky hillslopes (slope gradients over $30^{\circ}$ ) where mica-schists with abundant quartzite veins outcrop (Devonian-Carboniferous, fine grained, dark grey, with graphite and garnets, high schistosity and microfolding due to the intense tectonics which has been active since the Alpine orogeny) and stony slope deposits, $b$ ) gravely alluvial fans and c) alluvial plain (a few hundred meters wide).

Soils developed on all these geomorphic units show in general little evolution. In the valley floor soils are loams, with a low proportion of rock fragments. They have been classified by PUIGDEFÁBREGAS et al. (1999) as Typic Torrifluvent (NRCS-USDA, 1999). In the other geomorphic surfaces soils are both very fine loamy sands and very fine sandy loams according the Soil Survey Manual (SCHOENEBERGER et al., 2002) with a high proportion of rock fragments (from 20\% to $43 \%$ of gravels and stones of the total soil) and an almost complete rock fragment cover. They have been classified as Typic Torriorthent (NRCS-USDA, 1999). A large proportion of the rock fragments and the particles from the fine earth are platty micas (both muscovite and paragonite) (PUIGDEFABREGAS et al., 1999). All of them have a moderate content of organic matter $(2.5 \%)$, a very low electrical conductivity $(0.74$ $\mathrm{dS} / \mathrm{m})$, neutral $\mathrm{pH}$ and very low free calcium carbonate. 


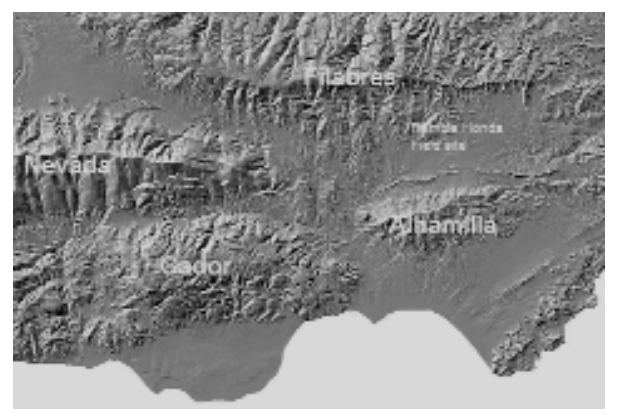

Fig. 1. A: Location of Rambla Honda field site in SE Spain, with indication of mountain ranges. B: aerial view of the terraces (photo Instituto de Cartografía de Andalucia, 2009), a = large bank cascading terraces at the valley bottom, $\mathrm{b}=$ narrow bench terraces in moderate to steep slopes.

The climate of the area is semiarid, with an annual precipitation of 265 $\mathrm{mm}$, measured in the in-situ meteorological station in the past 20 years (19892009), with a maximum in Autumn-Winter and a minimum in summer. The average annual temperature is $16.5^{\circ} \mathrm{C}$.

The present vegetation shows the substantial influence of man activities throughout the past centuries, limiting both biomass accumulation and brushwood development and favouring alpha-grass (Stipa tenacissima), cropped for its fibre before the second half of the $20^{\text {th }}$ century, and cereals (PUIGDEFÁBREGAS et al., 1999). At present, three main species dominate in the watershed: alpha grass in the steep rocky slopes, the legume shrub Anthyllis cytisoides in moderate slopes which had been cultivated for cereals, and the legume bush Retama sphaerocarpa on the valley bottom and on the abandoned large-bank cascading terraces besides the main channel. The annual grass Stippa capensis is found everywhere, but especially abundant on flat abandoned fields.

\subsection{Abandoned and semi-abandoned agricultural fields and terraces}

Large bank cascading terraces besides the main channel of the ephemeral river (rambla) (Figs 1B and 5) have earthen risers, which are 10 to $30 \mathrm{~cm}$ above the bank farming area. The donwslope parts of risers are usually stabilized with prickly pears (Opuntia ficus-indica). Only the overflows are made of stonework. As these terraces are quite flat and they are irrigated by means of artificial diversion channels (boqueras) only during major events (one every 
four years, DOMINGO et al., 2001), the parts of the banks near the risers can withstand up to $30 \mathrm{~cm}$ of water level. Such a hydraulic gradient along with the borrowing activity of animal (rabbits, tarantulas, etc.) triggers piping processes near the risers, and sometimes large amounts of soil (from a few cubic meters to several hundred) are eroded (Fig 2). A full range of abandonment status exists: the terraces abandoned long time ago show a relatively dense cover of bushes (Retama sphaerocarpa) which might be older than 5-10 years, while those tilled in the last 1 to 5 years show a quite generalised surface crust (physical type) with seedlings or very sparse young bushes of Retama sphaerocarpa.

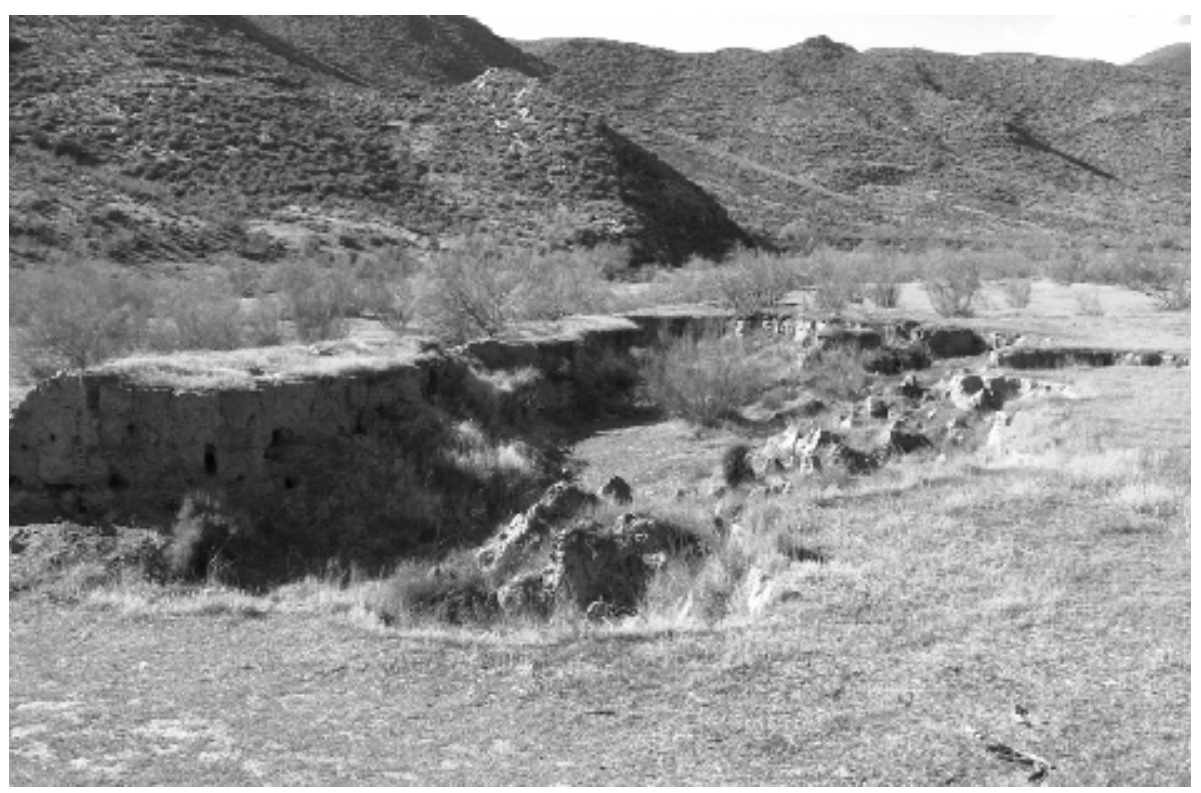

Fig. 2. Gully erosion derived from piping in large-bank terrace.

Other types of abandoned land include the alluvial fan surfaces and the narrow bench terraces with stony walls on steep, rocky slopes (either concave or convex, or even in drainage ways) covering most of the steep slopes (Fig 3) and sometimes found as isolated single terraces. Benches are mostly covered by herbs (Stipa capensis) and slopy contributing areas by sparse shrubs (mostly Anthyllis cytisoides). These terraces have stonework risers (locally known as balates) which, except a few cases, are very well preserved (Fig 4). 
WHY MOST AGRICULTURAL TERRACES IN STEEP SLOPES IN SEMIARID SE SPAIN REMAIN...

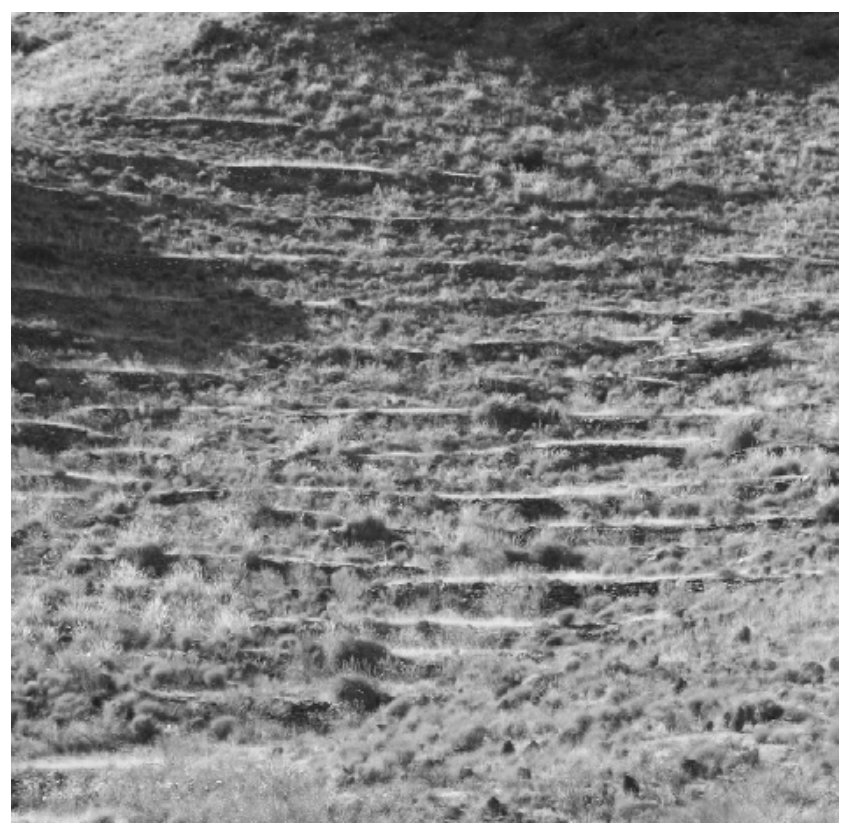

Fig. 3. Narrow-bench terraces in modderate to steep slopes: a = quite level banks were farmed; $\mathrm{b}=$ steep slope sectors contributed with runoff water to flat farmed sectors.

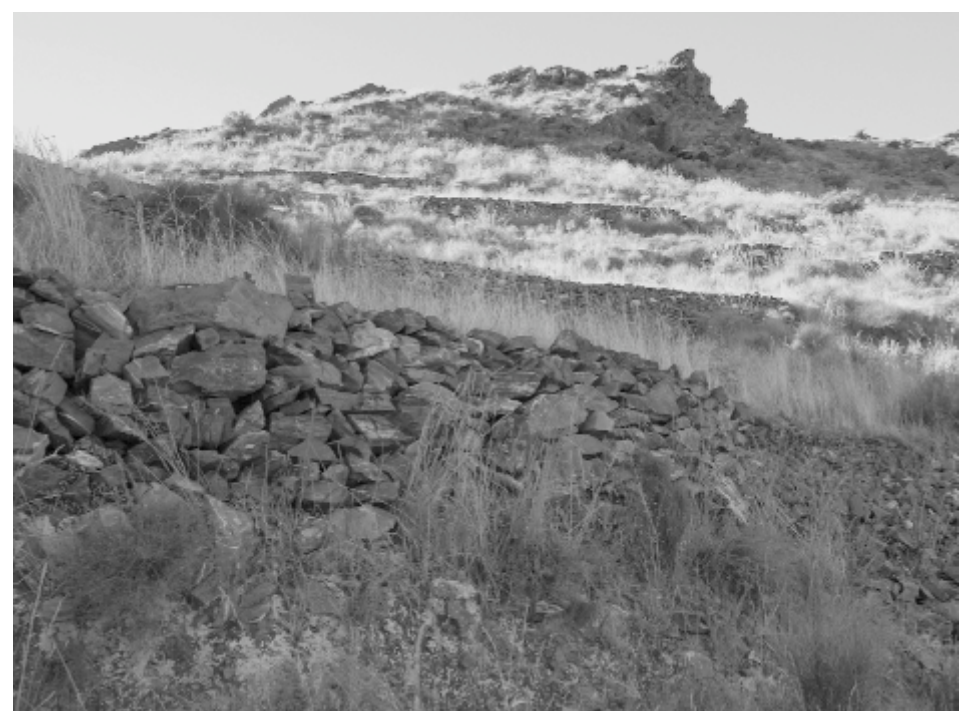

Fig. 4. Detail of narrow-bench terrace in moderate to steep slopes. 


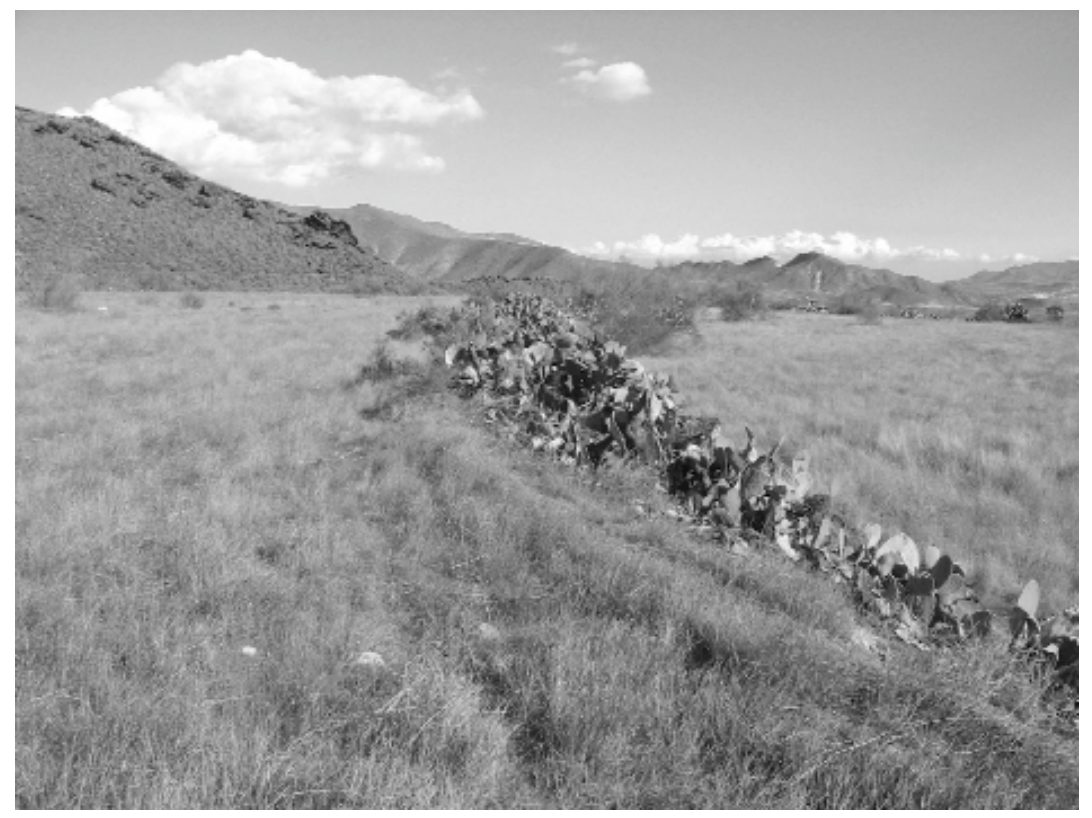

Fig. 5. Large-bank cascading terraces in the valley floor. Risers are earthen and many times stabilised by prickly pears.

\section{Methods}

\subsection{Identification of sites and landforms studied}

A previous field campaign allowed to identify nine sites representing the main surfaces in the area and in each one five replicate micro-sites were selected making a total of 45 micro-sites where the rain simulations were carried out.

The nine sites were the following:

a) flat part (bank) of the narrow bench terraces on concave terraced hillslopes.

b) steep water contributing areas upslope bench terraces on concave terraced hillslopes.

c) flat part (bank) of the narrow bench terraces on convex hillslopes. 
WHY MOST AGRICULTURAL TERRACES IN STEEP SLOPES IN SEMIARID SE SPAIN REMAIN...

d) steep water contributing areas upslope bench terraces on convex terraced hillslopes.

e) flat part (bank) of the narrow bench terraces on terraced drainageways.

f) slightly sloping alluvial fans.

g) large flat cascading terraces besides the ephemeral river.

h) large flat cascading terraces besides the ephemeral river, feeded by lateral hillslopes (jessour type).

i) steep colluvial deposits and/or steep bench terraces upslope rock outcrops and/or stonework risers in steep rocky hillslopes.

These sites belong to five landform units also previously surveyed and partly described in PUIGDEFÁBREGAS et al. (1998) and PUIGDEFÁBREGAS et al. (1999):

A) Flat, contour narrow-bench terraces (balates) (sites a, c, e).

B) Steep contributing areas upslope bench terraces (sites b, d).

C) Slightly sloping alluvial fans (site f).

D) Flat, large-bench terraces in the alluvial plain (sites g, h). (site i)

E) Steep colluvial deposits upslope rock outcrops in steep rocky hillslopes

\subsection{Site and soil characterization}

Two soil profiles up to the bedrock or up to a depth of $1.5 \mathrm{~m}$ were opened in every one of the 9 sites in which the rain simulation were performed (in total 18 soil profiles), and morphological descriptions (total depth, structure, presence of cutans, $\mathrm{HCl}$ reaction of surface and deep horizon) with emphasis in the top horizon and its surface (surface occupied by crusts, rock fragments, litter, herbs, shrubs and bushes) were done, as well as the following analysis: particle size analysis of the fine earth by the Robison pipette method, rock fragment content, organic matter content (oxidation with dichromate), $\mathrm{pH}$, electrical conductivity, calcium carbonate equivalent, and aggregate stability by both wet sieving (KEMPER \& ROSENAU, 1986) and the drop test (IMESON \& VIS, 1984). Ground cover including plants (herbs and shrubs), rock fragments and surface crusts of the sites where soil profiles were described were also obtained.

\subsection{Rainfall simulation}

A portable sprinkler-type rain simulator (CALVO et al., 1988) operating at a rainfall intensity of $50 \mathrm{~mm} / \mathrm{h}$ was used. Runoff was collected from $0.24 \mathrm{~m}^{2}$ 
circular plots within the target area bounded by a metal ring of $0.55-\mathrm{m}$ diameter and recorded every minute from $t=0$ to $t=90$ or until a constant value was reached. Other parameters were also recorded from every rainfall simulation: a) rain intensity by rain micro-gauges, b) time to runoff, c) initial soil water content at $10 \mathrm{~cm}$ ( in), d) final soil water content at $10 \mathrm{~cm}$ ( fi); e) infiltration front, f) sediment yield (by sampling water runoff after 8, 16 and 60 minutes and subsequent separation of solid particles by sieving through 50 and $20 \mathrm{~m}$ and by filtration at $0.5 \mathrm{~m}$ ).

Infiltration rates were estimated using a one-phased exponential decay model:

$$
\mathrm{y}=\mathrm{a}^{*} \exp \left(-\mathrm{k}^{*} \mathrm{x}\right)+\mathrm{I}_{\mathrm{c}^{\prime}}
$$

where $y$ is the instantaneous infiltration rate, $x$ is the time from the moment at which runoff started and $I_{c}$ is the steady-state infiltration rate. Parameters $a$ and $k$ were adjusted by least squares with Statistica 6 (Statsoft, 2005). It is assumed that evapotranspiration during rainfall simulations was negligible. Constant infiltration rate $I_{c}$ is similar to $F_{c}$ provided by the Horton equation used in many other studies in similar environments (e.g., LAVEE et al., 1991; CERDÀ et al., 1997; SOLÉ-BENET et al., 1997; IMESON, 1983; IMESON \& LAVEE, 1998; CALVO et al., 2003).

\subsection{Statistical analysis}

With all the hydrologic data, relationships with landforms types and attributes (including soil and vegetation) were sought through Spearman and Kruskall-Wallis tests using Statistica 6 (STATSOFT, 2005) and the distribution of key variables on the different type of terraces were also examined

\section{Results}

\subsection{Site and soil characteristics}

Tables $1,2 \mathrm{a}, 2 \mathrm{~b}$ contain the averages and standard errors of main soil and ground cover characteristics from the nine sites (table 1) and from the five landforms (tables $2 \mathrm{a}, 2 \mathrm{~b}$ ). Table 3 shows the Spearman rank correlations among all soil and ground cover variables.

Tables 1 and 2 show that plant cover is higher where slope gradients are lower (sites a, c, g, h and landforms A, D are quite flat surfaces) and that the 
relationship plant cover - slope gradient, though low, is significant. The relationships between herbs cover and slope are also significant but somewhat higher $(\mathrm{r}=-0.58)$, though slope is not significantly related to the shrub cover. The former relationship indicates that flat surfaces (banks of terraces) have a larger plant cover of herbs though a lower shrub cover. Herb and shrubs are negatively correlated $(\mathrm{r}=-0.64)$. However the visual impression (Fig 3) is opposite than the actual ground cover: slopes seem to have a larger plant cover than flat surfaces. Large-bank terraces $(g$ and $h$ ) have the lowest slope gradient though they have different plant cover because their different time since abandonment: while $g$ was tilled just a few years ago, it has a reduced plant cover and the surface is quite crusted, $h$, a jessourtype terrace abandoned longer time ago, has a much larger plant cover of both herbs and bushes (table 1) which have an important role in decreasing sediment yield (table 4). Plant cover also have significant and expected relationship with aggregate stability results (table 3); while the rock fragment content follows the opposite relationship with slope than plant cover.

Table 1. Averages and standard errors (SE) of main soil and ground cover characteristics per site.

\begin{tabular}{|c|c|c|c|c|c|c|c|c|c|c|c|}
\hline St: & 1'tent ax & Krias & Ans: & $\mathrm{Rr}$ & $\mathrm{nH}$ & $E C^{2}$ & $\left(x x^{\prime}\right)_{3}$ & $\mathrm{smal}$ & oll & day & CM \\
\hline 2 & $85.0 \div 24$ & $85 \div 7$ & $5.4: 1.7$ & $249 \cdot 5.2$ & 6.810 & $0.6 \div 0.1$ & $1.2 \div 0.2$ & $75.5 \div 0.2$ & $19.6 \div 0.2$ & 5.310 .4 & 1.810 .1 \\
\hline b & $30.2 \times 15.2$ & $92.5 \div 3$ & $16.0: 25$ & $37.8 \times 12$ & $7.2 \times 0.1$ & $0.8 \div 0.1$ & $0.4: 0.1$ & $68 \mid 6.8$ & $23.9 \div 6.5$ & 8.210 .4 & 3313 \\
\hline $\mathrm{c}$ & $70.0+14.5$ & $85+7$ & $1.4+0.8$ & $209+3.5$ & $69+0.3$ & & $0.5+0.2$ & 76. & & $60+08$ & 123 \\
\hline$d$ & 122 & $79 \pm 21.2$ & $143=1 \%$ & $45.7 \neq 0.7$ & $7.11=0$ & $0.5=0 \%$ & $11.3=0.1$ & $76.45 \pm 20$ & & $6.3 \pm 1.1$ & $1 \neq 0.9$ \\
\hline e & 11 & $100+0$ & $98+1.4$ & $209+0.2$ & $7.4+0.2$ & $1.0+0.3$ & $1.1+1.1$ & $76.4+8.66$ & $18.9+7$ & $48+1.6$ & $26+1.1$ \\
\hline c & $32.5+5.7$ & $73.3+30.5$ & $8.5+1.1$ & $350+1.1$ & $72+0.3$ & $0.7+0.2$ & $0.1+0.1$ & $79.0+29$ & $159+25$ & $5.2+0.6$ & $21+1.1$ \\
\hline 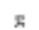 & $306 \pm 197$ & $5 \pm 7.1$ & $13 \pm 0.4$ & $84 \pm 11.5$ & $7.7 \pm 0.1$ & $1.1 \pm 0.3$ & $1.3 \pm 0.1$ & $367 \pm 279$ & $528 \pm 21.3$ & $10.5=3.7$ & $25 \pm 01$ \\
\hline in & $78.8+15.9$ & $5+0$ & $3.3+2.5$ & $15.3+0$ & $6.8+0$ & $0.4+0$ & $1.5+0$ & $72.7+0$ & $21.6+0$ & $58+0$ & $3.1+0$ \\
\hline $\mathrm{i}$ & $23.0 \div 69$ & $87.5 \times 3.5$ & $11.8 \div 0.8$ & $409 \div 1.7$ & $7.0: 0.4$ & $0.7 \div 0.2$ & $0.4 \cup 0.1$ & $68.8 \div 2.1$ & $24.9: 2.2$ & 6.310 .1 & 2.410 .6 \\
\hline
\end{tabular}

Concerning the soil particle sizes, sites $g, h$, and landform $\mathrm{D}$ at the bottom of the valley have the highest amount of fines (silt+clay), above $50 \%$, while the other sites and landforms only have around $30 \%$.

Table 2a. Averages and standard errors of main soil and ground cover characteristics.

\begin{tabular}{|c|c|c|c|c|c|c|c|c|c|c|c|c|}
\hline L.andform & $\begin{array}{r}\text { Pow } \\
(969)\end{array}$ & Llab cor & Sir cor & $\begin{array}{l}\text { shipe } \\
(0)\end{array}$ & $\begin{array}{l}\mathrm{N} \\
0\end{array}$ & $\rho \mathrm{HH}$ & $\begin{array}{c}\mathrm{Ex} \\
\mathrm{AS} \mathrm{m}\end{array}$ & $\begin{array}{c}\mathrm{Cx} \times 03 \\
\mathrm{Bii}\end{array}$ & $\begin{array}{l}\text { sed } \\
\text { (5) }\end{array}$ & (sit) & $\begin{array}{l}\text { cbly } \\
\text { sing }\end{array}$ & $\begin{array}{l}\text { UM } \\
(B)\end{array}$ \\
\hline A & $725=20$ & 66.5 & 60 & $6 \pm 1.3$ & $282 \pm 23$ & $7.1=0.1$ & $a 8=01$ & $0.9 \pm 02$ & $762=1.9$ & $18.5 \pm 1.6$ & $5.4 \pm 0.4$ & $26 \pm 0.6$ \\
\hline B & $30.9-9.4$ & 224 & 8.5 & $15.2+1.5$ & $41.7-4.8$ & $7.1-0.1$ & $a i_{i}-0.2$ & $0.3 \rightarrow 0.1$ & $72.2-3.8$ & $20.6+3.2$ & $72-1$ & $2.6 \div 0.9$ \\
\hline c: & $325-5.7$ & 22.4 & 101 & $8.5+1.4$ & $35.0+1.1$ & $7.2-0.3$ & $a 7-0.2$ & $0.1+a_{1}$ & $790-29$ & $15.9+2.5$ & $5.2+0.6$ & $2.1+1.1$ \\
\hline D & $517+146$ & 547 & 00 & $26+16$ & $107+64$ & $7.3=0.4$ & $09-03$ & $14+01$ & $187+202$ & $42.4+176$ & $89-27$ & $2.7+0.3$ \\
\hline$\pi$ & $23 n-69$ & 16.1 & 69 & $11 s+n s$ & $402-17$ & $7 \perp n A$ & $07-02$ & $04+01$ & $6 i R 8-21$ & $290+2.2$ & $62-01$ & $24-0.6$ \\
\hline
\end{tabular}


Aggregate stability results, both wet sieving and drop test (table $2 b$ ), do not show highly significant differences among sites or landforms, though the two highest mean values correspond to landforms $\mathrm{A}$ and $\mathrm{D}$ (terraces) and the two lowest to $\mathrm{C}$ and $\mathrm{E}$ (alluvial fans and slope deposits).

Table $2 \mathrm{~b}$. Averages and standard errors of the wet sieving (\% of resistant aggregates, Res Agg) and the drop test (number of drops necessary to break 30 aggregates, $\mathrm{N}^{\circ}$ Drops).

\begin{tabular}{ccc}
\hline Landliomn & $\begin{array}{c}\text { Res Agg } \\
(\%)\end{array}$ & $N^{\circ}$ Drops \\
\hline$\Lambda$ & $45.7 \mid 8.5$ & $186.7 \mid 39.4$ \\
B & $38.8 \pm 1.3$ & $154.0 \pm 30$ \\
$C$ & 39.2122 .7 & $138.0 \div 82.7$ \\
$D$ & $45.3 \pm 15.8$ & $229.9 \pm 131.8$ \\
$\Gamma$ & $31.2 \pm 15$ & $109.3 \pm 22.1$ \\
\hline
\end{tabular}

There are no significant differences among the landforms for the variables $\mathrm{pH}, \mathrm{EC}, \mathrm{CaCO}_{3}$ and $\mathrm{OM}$ content.

Table 3. Spearman rank correlations among landform variables (significant values in red).

\begin{tabular}{|c|c|c|c|c|c|c|c|c|c|c|c|c|c|}
\hline & $\mathrm{Pcov}$ & herhs & shrubs & slope & total RF & wet sicy & drop test & $\mathrm{pH}$ & $\mathrm{HC}$ & $\mathrm{COACa}$ & sand & silt & clay \\
\hline herbs & 0.48 & & & & & & & & & & & & \\
\hline shrubs & 0.10 & -064 & & & & & & & & & & & \\
\hline sklope & -0.46 & $-0,58$ & 0.39 & & & & & & & & & & \\
\hline total Rl: & -0.48 & -0.61 & 0.52 & 0.83 & & & & & & & & & \\
\hline wet siev & 0.61 & 0.53 & -0.14 & -0.15 & -0.21 & & & & & & & & \\
\hline drop test & 0.47 & 0.62 & -0.31 & -0.18 & $-0.2)$ & 0.85 & & & & & & & \\
\hline $\mathrm{pH}$ & -0.34 & 0.21 & -0.40 & -0.10 & -0.23 & -0.41 & -0.20 & & & & & & \\
\hline FC & -0.10 & 0.58 & -0.24 & -0.36 & -0.37 & -0.07 & 0.11 & 0.57 & & & & & \\
\hline $\mathrm{CO} 3 \mathrm{Ca}$ & 0.46 & 0.66 & 0.67 & -0.55 & -0.70 & 0.11 & 023 & 0.13 & 0.16 & & & & \\
\hline sand & 0.23 & -0.48 & 0.31 & 0.32 & 0.27 & 0.00 & -0.07 & -025 & -0.46 & -0.34 & & & \\
\hline silt & -0.09 & 0.60 & -0.37 & -0.36 & -0.39 & 0.15 & 0.18 & 0.25 & 0.47 & 0.42 & -0.96 & & \\
\hline clay & -0.41 & 0.30 & -0.18 & -10.19 & -0.03 & -0.27 & -0.02 & 0.26 & 0.44 & 0.07 & -0.78 & 0.62 & \\
\hline $\mathrm{OM}$ & 0.21 & 0.68 & -10.29 & -10.30 & -0.33 & 0.30 & 0.51 & 0.20 & 0.74 & 0.27 & -0.51 & 0.53 & 0.50 \\
\hline
\end{tabular}

\subsection{Hydrological characteristics with regards to landform and soil parameters}

Results from all rainfall simulations are presented in table 4. Significant ( $\mathrm{p}$ $<0.05)$ Spearman rank correlations have been found between total runoff and sediment yield $(\mathrm{r}=0.52)$, steady infiltration Ic and sediment yield $(\mathrm{r}=-0.58)$, sediment yield and infiltration fronts $(r=-0.38)$, sediment yield and time to runoff $(r=-0.33)$, total sediments and total runoff $(r=0.52)$ and also to slope gradient $(\mathrm{r}=0.46, \mathrm{p}=0.003)$. 
WHY MOST AGRICULTURAL TERRACES IN STEEP SLOPES IN SEMIARID SE SPAIN REMAIN...

Table 4. Hydrologic parameters obtained in the rainfall simulations.

\begin{tabular}{|c|c|c|c|c|c|c|c|c|c|c|}
\hline Surlace & $\begin{array}{c}\text { seal yeld } \\
\text { yim }\end{array}$ & $\begin{array}{c}\text { mIT uxel } \\
(\%)\end{array}$ & 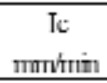 & $\begin{array}{c}\mathrm{kx} \mathrm{m} \mathrm{II}^{-} \\
\mathrm{mm}\end{array}$ & 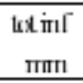 & $\begin{array}{c}\text { milTL-16 } \\
\text { mmm }\end{array}$ & $\begin{array}{c}\text { inI fruxtl } \\
(\mathrm{cm})\end{array}$ & 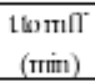 & $\begin{array}{l}\theta_{\text {ini. }} \\
(\%)\end{array}$ & $\begin{array}{l}\theta \text { fin } \\
(\%)\end{array}$ \\
\hline a & 0.33 & 6.2 & 0.48 & 5.59 & 54.52 & 1.69 & $\mathrm{~m}$ & 39 & 0.3 & 14.4 \\
\hline a & 1.18 & 44.3 & 0.32 & 32.15 & 40.15 & 5.54 & 1.5 & 6.5 & 0.3 & 14.4 \\
\hline a & $\mathrm{m}$ & 45.9 & 0.36 & $\mathrm{mII}$ & $\mathrm{m}$ & $\mathrm{m}$ & $\mathrm{m}$ & 8 & 0.3 & 11.1 \\
\hline a & $\mathrm{m}$ & 3.2 & 0.42 & $\mathrm{~m}$ & $\mathrm{~m}$ & $\mathrm{~m}$ & $\mathrm{~m}$ & 17 & 0.4 & 146 \\
\hline as & 0.23 & 100 & 0.55 & 8.16 & 66.94 & 1.46 & 26.5 & 22.5 & 0.5 & 20.5 \\
\hline b & 3.77 & 72.7 & 0.12 & 36.2 & 13.54 & 5.58 & 2.5 & 4.5 & 0.4 & 14.4 \\
\hline b & 0.47 & 50.7 & 0.31 & 40.52 & 34.14 & 6.6 & 9 & 9 & 0.5 & 12.6 \\
\hline $\mathrm{b}$ & 8.70 & 556 & 0.23 & 35.33 & 23.94 & 5.17 & 4.5 & 4.5 & 0.5 & 126 \\
\hline $\mathrm{b}$ & 1.88 & 430 & 0.35 & 23.36 & 31.03 & 5.09 & 12 & 6.5 & 0.6 & 15.9 \\
\hline $\mathrm{b}$ & 2.51 & 27.0 & 0.42 & 19.03 & 49.18 & 2.72 & 13 & 8.5 & 0.2 & 12.3 \\
\hline c & 0.66 & 30.4 & 0.49 & 22.73 & 45.69 & 5.78 & 17 & 20 & 2.7 & 17 \\
\hline $\mathrm{c}$ & 0.58 & 436 & 0.28 & 23.79 & 30.06 & 3.93 & 9.5 & 7 & 3.8 & 156 \\
\hline $\mathrm{c}$ & 025 & 41.8 & 0.22 & 24.04 & 43.89 & 6.08 & 30 & 6 & 1.9 & 17.5 \\
\hline c & 0.14 & 6.0 & 0.63 & 3.43 & 62.41 & 1.84 & 30 & 33.5 & 2.4 & 17.1 \\
\hline $\mathrm{c}$ & 0.30 & 16.4 & 0.51 & 8.69 & 62.42 & 4.03 & 52 & 22 & 2.5 & 166 \\
\hline d & 622 & 49.9 & 0.38 & 37.9 & 39.05 & 623 & 24 & 4.5 & 1.8 & 192 \\
\hline d & 8.34 & 802 & 0.05 & 55.84 & 9.7 & 9.15 & 10 & 5 & 0.5 & 156 \\
\hline d & 3.09 & 58.8 & 0.16 & 41.75 & 22.1 & 5.62 & 20 & 5 & 0.3 & 11.1 \\
\hline d & 1.44 & 58.8 & 0.19 & 42.2 & 22.98 & 6.76 & 22 & 8.5 & 02 & 13.8 \\
\hline e & 028 & 122 & $\mathrm{~m}$ & 7.94 & 67.15 & 1.71 & 26 & 5.5 & $\mathrm{~m}$ & $\mathrm{~m}$ \\
\hline $\mathrm{c}$ & 0.31 & 9.9 & 0.58 & 7.64 & 62.62 & 1.46 & 22 & 14.5 & 02 & 126 \\
\hline c & 0.60 & 25.7 & 0.41 & 12.91 & 40.64 & 4.6 & 10 & 5 & 0.1 & 135 \\
\hline f & 0.31 & 12.4 & 0.44 & 9.38 & 49.26 & 2.14 & 14 & 6 & 7.1 & 109 \\
\hline $\mathrm{f}$ & 0.38 & 236 & 0.40 & 12.31 & 36.88 & 2.35 & 29 & 9.5 & 5.3 & 15.4 \\
\hline f & 751 & 152 & 0.37 & 37.89 & 40.7 & 709 & 19 & 11 & 0.4 & 13.1 \\
\hline f & 5.46 & 513 & 0.30 & 42.06 & 33.41 & 6.93 & 14 & 11 & 0.3 & 12.3 \\
\hline ؟ & 0.73 & 11.7 & 0.32 & 33.09 & 36.04 & 1.17 & 16 & 7 & 0.3 & 142 \\
\hline$g$ & $\mathrm{~m}$ & 6.4 & $\mathrm{~m}$ & 5.41 & 61.12 & 0.53 & 27 & 7 & 02 & 9.9 \\
\hline$g$ & 937 & 9.9 & 020 & 17.62 & 55.04 & 2.14 & 19 & 35.5 & 02 & 208 \\
\hline$g$ & 12.8 .5 & 570 & 0.27 & 45.49 & 28.81 & 687 & 19 & 5 & 0.5 & 13.7 \\
\hline$g$ & 297 & 256 & 0.40 & 23 & 48.57 & 181 & 14 & 13.5 & 1.1 & 319 \\
\hline $\mathrm{h}$ & 126 & 32.4 & $\mathrm{~m}$ & 24.54 & 43.31 & 4.04 & 10 & 15 & 1.2 & 27.2 \\
\hline h & 2.62 & 47.5 & 0.15 & 30.16 & 3026 & 624 & 9 & 15 & 12 & 272 \\
\hline $\mathrm{h}$ & 0.83 & 62.1 & $\mathrm{~m}$ & 40.87 & 24.6 & 834 & 9 & 8.5 & 7.5 & 258 \\
\hline h & 1.62 & 53.4 & 0.22 & 40.34 & 29.98 & 5.16 & 21 & 10.5 & 1.7 & 16.9 \\
\hline $\mathrm{i}$ & 2.72 & 57.4 & 0.24 & 15.79 & 28.17 & 626 & 10.5 & 6 & 0.5 & 109 \\
\hline $\mathrm{i}$ & 2.77 & 27.1 & 0.20 & 26.4 & 45.69 & 281 & 8 & 14 & 0.3 & 11.7 \\
\hline $\mathrm{i}$ & 159 & 74.1 & 0.16 & 46.87 & 15.83 & 8.47 & 6.5 & 3 & 0.6 & 12.1 \\
\hline $\mathrm{i}$ & 1.31 & 56.5 & 0.24 & 36.05 & 2.5 .57 & 6.39 & 9.5 & 7 & 0.5 & 12.7 \\
\hline $\mathrm{i}$ & 2.13 & 53.9 & 0.27 & 31.12 & 24.53 & 5.62 & 10 & 5 & 5.8 & 18.5 \\
\hline
\end{tabular}

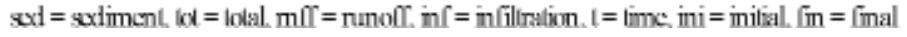


Table 5 shows the Spearman rank correlations between the soil-landform characteristics and the hydrological ones obtained from the rainfall simulations. Significant correlations exist between plant cover and most hydrological values: sediment yield, steady infiltration, time to runoff, total runoff, total infiltration, runoff coefficient and final soil water content. The coefficient of determination increases when considering the relationships of herbs cover with steady infiltration $(r=0.55)$ instead of total plant cover.

Table 5. Spearman rank correlation between landform variables and hydrological values (significant values in red).

\begin{tabular}{|c|c|c|c|c|c|c|c|c|c|c|}
\hline & sed yicld & Ic & inf front & t to mf & $\theta_{\text {in }}$ & $\theta_{\text {fi }}$ & tot part & $\operatorname{tot} \mathrm{m} \int \mathrm{T}$ & Lot inf & $\mathrm{m} f \mathrm{cos} \int \mathrm{T}$ \\
\hline Pcov & -0.46 & 0.42 & 027 & 0.49 & 0.15 & 0.54 & -0.36 & -0.45 & 0.41 & -0.42 \\
\hline herb cov & -0.15 & 0.55 & 026 & 034 & 0.16 & 0.43 & -0.18 & -0.44 & 036 & -0.47 \\
\hline slope & 0.26 & -029 & -0.34 & -0.59 & -0.10 & -0.49 & 028 & 0.39 & -0.45 & 0.46 \\
\hline total RF & 0.12 & $-0) 39$ & $-0,06$ & -0.29 & 001 & -0.39 & 021 & 0.40 & -0.31 & 0.31 \\
\hline wel sicv & 0.15 & 0.41 & -0.07 & 0.11 & 0.14 & 0.37 & 0.24 & 0.14 & -0.0 .3 & -0.03 \\
\hline drop test & 0.01 & 0.42 & 0.09 & 0.15 & 0.04 & 0.15 & 0.01 & -0.07 & 0.04 & -0.19 \\
\hline $\mathrm{pH}$ & -0.04 & 0.41 & 0.39 & 0.18 & -0.35 & -0.22 & -020 & -0.58 & 0.72 & -0.42 \\
\hline $\mathrm{EC}$ & -0.10 & 0.35 & 025 & 0.14 & -0.30 & -0.13 & -0.18 & -0.54 & 0.47 & -0.40 \\
\hline $\mathrm{CO}_{3} \mathrm{C} \mathrm{a}$ & -0.19 & 0.18 & 0.04 & 0.15 & -0.07 & 0.50 & -0.27 & $-0) 26$ & 0.22 & -10.26 \\
\hline sand & $-1) 23$ & $-0,04$ & 0.31 & -0.12 & 0.17 & -0.06 & -0.06 & 0.01 & 0.09 & -10.07 \\
\hline silt & 0.27 & 0.13 & -0.27 & 0.08 & -0.20 & 0.14 & 0.09 & -0.06 & -0.01 & 0.00 \\
\hline clay & 0.16 & -0.16 & -0.22 & 0.02 & -0.10 & -0.08 & 0.03 & -0.01 & -0.15 & 0.13 \\
\hline $\mathrm{OM}$ & -022 & 028 & -0.04 & 0.00 & 0.09 & 0.04 & -0.22 & -033 & 0.14 & -0.18 \\
\hline
\end{tabular}

sed yield - scdiment yicld, inf- infiltration, in - initial, fi - final, part - particles, tot - total, mff - munoff

$\mathrm{PCOV}^{-}$plant cover, $\mathrm{RF}-$ mek fragments, sicv - sicving, $\mathrm{HC}$ - clectrical ennductivity $(\mathrm{M}$ - organic matter

Slope gradient is significantly correlated to time to runoff, total infiltration and final soil water content (all of them negatively) and to runoff coefficient (positively).

Only a soil attribute, the aggregate stability by means of the drop test, is significantly correlated to the steady infiltration. Other correlations of soil variables with hydrological ones, i.e. $\mathrm{pH}, \mathrm{EC}$ and total carbonates with total runoff, total infiltration and runoff coefficients might have uncertain explanations. Organic matter and particle size do show large differences among sites and landforms (Tables $1 \& 2 \mathrm{a}$ ) and this fact might explain the lack of significant relationships with hydrological variables.

Data from table 4 have also been tested with Kruskall-Wallis tests to ascertain possible different behaviours of the two main hydrological 
parameters, i.e., steady infiltration (Ic) and sediment yield with regards to landform types. Data in tables 6 and 7 where pairwise significances are indicated, show that narrow-bench terraces, slope deposits and contributing areas to bench terraces have sediment yields (table 6) and steady infiltrations (Table 7) significantly different than other landforms. Large bank terraces (D) show marginally significant differences $(p=0.078)$ with other landforms. As shown in table 4 , in general, sediment yields are minimum in flat terrace areas and maximum in the corresponding steep contributing areas upslope terrace banks.

Table 6. Multiple comparison p values. Dependent variable: Sediment yield. Independent grouping vairable $=$ Landform. Kruskall-Wallis test: $\mathrm{H}(4, \mathrm{~N}=37)=19.79, \mathrm{p}=0.0005$.

\begin{tabular}{ccccc}
\hline & $\mathbf{A}$ & $\mathbf{B}$ & $\mathbf{C}$ & $\mathbf{D}$ \\
\hline $\mathrm{B}$ & 0.0012 & & & \\
$\mathrm{C}$ & 0.5013 & 1.0000 & & \\
$\mathrm{D}$ & 0.0050 & 1.0000 & 1.0000 & \\
$\mathrm{E}$ & 0.0819 & 1.0000 & 1.0000 & 1.0000 \\
\hline
\end{tabular}

Table 7. Multiple comparison p values. Dependent variable: Ic (steady infiltration). Independent grouping vairable $=$ Landform. Kruskall-Wallis test: $\mathrm{H}(4, \mathrm{~N}=36)=15.93, \mathrm{p}=0.0031$.

\begin{tabular}{ccccc}
\hline & A & B & C & D \\
\hline B & 0.0234 & & & \\
C & 1.0000 & 0.8194 & & \\
D & 0.0782 & 1.0000 & 0.9877 & \\
E & 0.0362 & 1.0000 & 0.6275 & 1.0000 \\
\hline
\end{tabular}

\section{Discussion}

Forty five rainfall simulations at an average intensity of $48 \mathrm{~mm} / \mathrm{h}$ (5 years return period) in five landforms essentially associated to abandoned agricultural terraces have revealed that runoff coefficients and total infiltration are related to some landform attributes, like plant cover (mostly herbs) and slope gradient. The increasing sequence for infiltration is: $\mathrm{E}<\mathrm{B}-\mathrm{D}$ $<\mathrm{C}<\mathrm{A}$. Other hydrological properties like steady infiltration are related to aggregate stability. This last property is significantly correlated to plant cover (total plant cover, which includes annuals and shrubs) which is maximum for 
herb cover in flat areas (both narrow-bench and large-bank terraces), as well as with infiltration values. Sediment yields are in general of low magnitude, and they are significantly correlated, though negatively, to plant cover and also to flat landforms.

All these result partly agree with those found by LESSCHEN et al. (2008) who studied semiarid abandoned terraces in El Carcavo basin (Murcia, SE Spain) on soils developed over limestone and dolomite. They agree in the fact that abandoned, large-bank cascading terraces at the valley bottom (sites $g$ and $h$ ) are prone to piping and gullying: see results in table 4 (site $g$ ) and figure 2. However, in all other sites in Rambla Honda $(a, b, c, d, e, f, i)$ the armouring effect of a quite continuous rock fragment cover considerably reduces sediment yield, though somewhat less in sloping areas (sites $b, d, f, i$ ) and also as a consequence of fines exhaustion, despite the possible large amounts of runoff water produced upslope both by impervious rock outcrops and steep slope deposits, were expected to produce substantial erosion, given the relatively low aggregate stability of these soils (table $2 b$ ). This armouring effect was previously described by PUIGDEFABREGAS et al. (1999) to explain the relatively low sediment yield values in un-terraced Rambla Honda slopes under natural rainfall. And the low magnitude of yielded sediments was also reported by both NICOLAU et al. (1996) from rainfall simulations carried out in an un-terraced catena in Rambla Honda. SOLE-BENET et al. (2002) reported that during the cultivation of Rambla Honda soils or just after their agricultural abandonment, sediment yields could have been much higher under rain intensities similar to those tested in this research due to the fact that large amounts of fines were available at the soil surface because of the tillage, even done by animal traction, but since the abandonment and once the rock pavement sieving crust (VALENTIN \& BRESSON, 1992) is formed, its armouring effect decreases substantially sediment yields under later rainfall events (SOLE-BENET et al., 2002). Moreover CANTON et al. (2009) reported about the relatively low aggregate stability of most soils in that catena. Similarly, LESSCHEN et al. (2008) reported that plant cover has a positive role in enhancing infiltration and reducing sediment yield. The differences observed among the five landforms (tables $2 a, 2 b$ ) contribute to explain differences in runoff, derived infiltration and sediment yield. Soil morphology also contributes to understand the importance of ground cover on runoff: a surface layer of platty gravels on the top of the soil acts either as a buffer layer to favour infiltration (in flat or moderately sloping surfaces). However, when rock fragment are embedded, totally or partly, which sometimes occurs in steep slopes in Rambla Honda, they act as sealed surfaces (POESEN et al., 1990) favouring runoff. In the almost flat terraces at 
the valley bottom, as the content of rock fragments is very reduced, mechanical surface crusts (very fine sands and silts mostly of platty, micaceous nature) are common and explain the relatively high sediment yield in this flat terrain: under low or moderate intensity rains, infiltration dominates, but under high intensity rains, soil erosion might be important when sediments can be evacuated out of the system, like under piping conditions.

The fact that abandoned fields in the valley floor show quite high runoff coefficients and the highest production of sediments, can be explained by the sedimentological characteristics of soil materials: dominance of micaceous very fine sands and silts, layering and surface crusting. The narrow range of particle sizes along with low aggregate stability favours piping (GALLART et $a l ., 2002)$ and piping erosion is widespread in cascading terraces of the Rambla Honda valley bottom. Besides the influence of the soil material, piping is caused by the hydraulic gradients into soil macropores (both dessication cracks and animal burrowing) due to flooded terraces on special runoff events ocurring with a frequency of about 4 years (DOMINGO et al., 2001).

As the lowest values in runoff coefficients and eroded particles have been obtained in narrow bench terraces, it clearly indicates the positive role of such structures for soil and water conservation, at least under abandonment condition.

\section{Conclusions}

The question why most agricultural terraces with stony walls in steep slopes in semiarid SE Spain remain well preserved since their abandonment 50 years ago can now be answered. Such terraces have a large infiltration capacity because of their gravelly, loamy-sand nature and a substantial cover of both herbs and rock fragments (on the top of the surface and not embedded), all of which reduce the production of sediments. However, in the same area though in the alluvial valley, and on relatively similar soils, though less gravelly, large-bank cascading terraces with earthen risers have a lower infiltration capacity due to its surface crusting (structural and depositional crusts), and a low plant cover during many months, all of which can produce large amounts of sediments specially under flooding conditions.

The hydrologic values of the different terrace type (steady infiltration, total sediment yield, total runoff coefficient) obtained from rainfall simulations are significantly related to the ground cover (plants and rock fragments) and to some soil properties, essentially aggregate stability. 
Tillage enhances infiltration and increases soil WHC, but also increases the risks for high sediment yields when the soil is bare. Land abandonment, mainly by means of surface crusting, decreases both infiltration and WHC but induces opposite erosion behaviours: when rock fragments are abundant in the soil, a rock fragment cover develops which protects soil against erosion process, but when the fine earth forms the surface layer, physical crusting appears which reduce infiltration and enhance sediment production.

\section{Acknowledgments}

This work received financial support from several organisations: a) Plan Nacional de I+D+I (projects PROBASE, ref. CGL2006-11619/HID and PREVEA, ref CGL2007-63258/BOS), Junta de Andalucia (proyecto "Balance hídrico en zonas degradadas semiáridas", P06-RNM-01732 and proyecto "Efectos de las costras físicas y biológicas del suelo sobre el balance de agua y la erosión en ambientes semiáridos" RNM-3614), b) Ministerio de Medio Ambiente, Medio Rural y Marino, through the RESEL (Spanish Network of Field Stations for Soil Erosion and Desertification Monitoring), c) the EC-DGRTD-6th Framework Research Programme, sub-priority 1.1.6.3, Research on Desertification (project "DESIRE, Desertification Mitigation and Remediation of land - a global approach for local solutions", contract \# 037046). The authors also thank Andrew Adams, Alfredo Durán and Montse Guerrero for their invaluable help in field and laboratory assistance.

\section{References}

ARNAEZ, J. \& ORTIGOSA, L., 1993. Erosión hídrica superficial en campos abancalados del Sistema Ibérico riojano (valles de Leza-Jubera). Geographicalia, 1993: 33-45.

BALLAIS, J.L. 1990. Terrasses de culture et jessours du Maghreb oriental. Méditerranée, 71(3-4): 51-53.

BOWYER-BOWE, T.A.S. \& BURT, T.P., 1989. Rainfall simulators for investigating soil response to rainfall. Soil Technology, 2: 1-16.

CALVO-CASES, A., GISBERT, J.M., PALAU, E., \& ROMERO, M., 1988. Un simulador de lluvia portátil de fácil construcción. In Sala, M. \& Gallart, F. (eds) Métodos y técnicas para la medición en el campo de procesos geomorfológicos. Monografías de la Sociedad Española de Geomorfología, pp 6-15, Zaragoza, Spain. 
WHY MOST AGRICULTURAL TERRACES IN STEEP SLOPES IN SEMIARID SE SPAIN REMAIN...

CALVO-CASES, A., BOIX-FAYOS, C. \& IMESON, A.C., 2003. Runoff generation, sediment movement and soil water behaviour on calcareous (limestone) slopes of some Mediterranean environments in southeast Spain. Geomorphology, 50(1-3): 269-291.

CAMMERAAT, E.L.H., WILLOT, S.J., COMPTON, S.G., \& INCOLL, L.D., 2002. The effect of ant's nests on the physical, chemical and hydrological properties of a range soils in semi-arid Spain. Geoderma, 105: 1-20.

CAMMERAAT, E.L.H., 2004. Scale dependent thresholds in hydrological and erosion response of a semi-arid catchment in southeast Spain. Agriculture, Ecosystems \& Environment, 104(2): 317-332.

CANTÓN, Y., SOLÉ-BENET, A., ASENSIO, C., CHAMIZO, S. \& PUIGDEFÁBREGAS, J., 2009. Aggregate stability in range sandy loam soils. Relationships with runoff and erosion. Catena, 77: 192-199.

CERDÀ, A., 1994. The response of abandoned terraces to simulated rainfall. In: Rickson, R.J. (Ed.), Conserving soil resources. European perspective. CAB International, , pp. 44-55, Wallingford.

CERDÀ, A., IBÁÑEZ, S., \& CALVO, A., 1997. Design and operation of a small and portable rainfall simulator for rugged terrain. Soil Technology, 11: 163170.

DOMINGO, F., VILLAGARCÍA, L., BOER, M. M., ALADOS-ARBOLEDAS, L. \& PUIGDEFÁBREGAS, J., 2001. Evaluating the long-term water balance of arid zone stream bed vegetation using evapotranspiration modelling and hillslope runoff measurements. Journal of Hydrology, 243: 17-30.

FANG, Z.S., ZHOU, P.H., LIU, Q.D., REN, L.T. \& ZHAND, H.X., 1981. Terraces in the loess plateau of China. In: Morgan, R.P.C. (ed.) Soil Conservation problems and prospects. John Wiley \& sons, pp 481-513, Chichester.

FAULKNER, H., RUIZ, J., ZUBOWSKY, P., \& DOWNWARD, S., 2003. Erosion risk associated with rapid and extensive clearances on dispersive materials near Sorbas, S.E. Spain. Environmental Science and Policy, 6: 115127.

GALLART, F., SOLÉ, A., LÁZARO, R. \& PUIGDEFÁBREGAS, J., 2002. Badland systems in the Mediterranean. In L.J.BULL \& M.J.KIRKBY (eds.) Dryland Rivers: hydrology and geomorphology of semi-arid channels, chap. 10. John Wiley \& sons: pp 299-326.

GARCIA LATORRE, J. \& GARCIA LATORRE, J. 2007. Almería hecha a mano. Una historia ecológica. Fundación Cajamar. 362 pp., Almería.

GARCIA-RUIZ, J M. \& LASANTA-MARTINEZ, T., 1990. Land use changes in the Spanish Pyrenees. Mountain Research and Development, 10(3): 267-279.

GROVE, A.O. \& RACKHMAN, O., 2001. The nature of Mediterranean Europe, an ecological history. Yale University Press. 
IMESON, A., 1983. Studies of erosion thresholds in semi-arid areas: field measurements of soil loss and infiltration in Northern Morocco. Catena Suppl., 4: 79-90.

IMESON, A.C. \& VIS, M., 1984. Assessing soil aggregate stability by waterdrop impact ans ultrasoci dispersion. Geoderma, 34: 185-200.

IMESON, A.C. \& LAVEE, H., 1998. Soil erosion and climate change: the transect approach and the influence of scale. Geomorphology, 23(2-4): 219227.

LAVEE, H., IMESON, A.C., PARIENTE, S., \& BENYAMINI, Y., 1991. The response of soils to simulated rainfall along a climatological gradient in an arid and semi-arid region. In: H.R. BORK, J. DE PLOEY \& A.P. SCHICK (Eds): Erosion, transport and deposition processes - theories and models. Catena Verlag, pp. 19-37, Cremlingen.

INBAR, M. \& LLERENA, C.A., 2000. Erosion Processes in High Mountain Agricultural Terraces in Peru. Mountain Research and Development, 20(1): 72-79.

KEMPER, W.D. \& ROSENAU, R., 1986. Aggregate stability and size distribution. In: A. Klute (ed.): Methods of soil analysis. Part 1: Physical and mineralogical methods. Americam Society of Agronomy: 425-442, Madison, Wi.

KOULOURI, M. \& GIOURGA, C., 2007. Land abandonment and slope gradient as key factors of soil erosion in Mediterranean terraced lands. Catena, 69(3): 274-281.

LASANTA, T., ARNAEZ, J., OSERIN, M \& ORTIGOSA, L.M., 2001. Marginal lands and erosion in terraced fields in the Mediterranean mountains: a case study in the Camero Viejo (Northwestern Iberian System, Spain). Mountain Research and Development, 21(1): 69-76.

LESSCHEN, J.P., CAMMERAAT, L.H., \& NIEMAN,P., 2008. Erosion and terrace failure due to agricultural land abandonment in a semi-arid environment. Earth Surface Processes and Landforms, 33: 1574-1584.

LLERENA, C.A., INBAR, M. \& BENEVIDES, M.A., 2004. Conservación y abandono de andenes. Universidad Nacional Agraria La Molina y Universidad de Haifa, $216 \mathrm{p}$.

NICOLAU, J.M., SOLÉ BENET, A., PUIGDEFÁBREGAS, J. \& GUTIÉRREZ, L., 1996. Effects of soil and vegetation on runoff along a catena in semiarid Spain. Geomorphology, 14: 297-309.

NRCS-USDA, 1999. Soil Taxonomy. A basic system of soil classification for making and interpreting soil surveys, $2^{\text {nd }}$ edition. Agriculture Handbook $\mathrm{N}^{\circ} 486$. National Resources Conservation Service, USDA, Washington, D.C., USA.

POESEN, J., INGELMO-SÁNCHEZ, F. \& MÜCHER, H.J., 1990. The hydrological response of soil surfaces to rainfall as affected by cover and 
WHY MOST AGRICULTURAL TERRACES IN STEEP SLOPES IN SEMIARID SE SPAIN REMAIN...

position of rock fragments in the top layer. Earth Surface Processes and Landforms, 15: 653-671.

PUIGDEFÁBREGAS, J., DEL BARRIO, G., BOER, M. GUTIÉRREZ, L. \& SOLÉ-BENET, A., 1998. Differential responses of hillslope elements to rainfall events in a semi-arid area. Geomorphology, 23: 337-351.

PUIGDEFÁBREGAS, J., SOLÉ-BENET, A., GUTIÉRREZ, L., DEL BARRIO, G. \& BOER, M., 1999. Scales and processes of water and sediment redistribution in dryland: results from Rambla Honda field site in SE Spain. Earth Science Reviews, 48: 39-70.

SALAS, D., 2004. Andenes, ecosistema frágil. En LLERENA, INBAR \& BENAVIDES (eds): Conservación y abandono de andenes, Universidad Nacional Agraria La Molina, Perú, 216 p.

SCHIETTECATTE, W., OUESSAR, M., GABRIELS, D., TANGHE, S., HEIRMAN, S., \& ABDELLI, F., 2005. Impact of water harvesting techniques on soil and water conservation: a case study on a micro catchment in southeastern Tunisia. Journal of Arid Environments, 61(2): 297313.

SCHOENEBERGER, P.J., WYSOCKI, D.A., BENHAM, E.C., \& BRODERSON, W.D. (editors), 2002. Field book for describing and sampling soils, Version 2.0. Natural Resources Conservation Service, National Soil Survey Center, Lincoln, NE.

SCOGING, H., 1982. Spatial variations in infiltration, runoff and erosion on hillslopes in semi-arid Spain. in Bryan and Yair (Eds.): Badland Geomorphology and Piping. Geo Books, pp. 47-79, England.

SOlÉ-BENET, A., CALVO, A., CERDÁ, A., LÁZARO, R., PINI, R. \& BARBERO, J., 1997. Influence of micro-relief patterns and plant cover on runoff related processes in badlands from Tabernas (SE Spain). Catena, 31(1-2): 23-38.

SOLÉ-BENET, A., PINI, R. \& RAFFAELLI, M., 2002. Hydrological consequences of soil surface type and condition in colluvial mica-schist soils after agricultural abandonment. In J.L. Rubio, R.P.C. Morgan, S. Asíns, V. Andreu (eds.) Man and soil at the third millenium (3rd Int. Congress of the European Society for Soil Conservation), vol I, , Geoforma Ediciones, pp. 523-533, Logroño, Spain.

STATSOFT., 2005. Statistica (data analysis software system), version 7.1. www.statsoft.com.

VALENTIN, C. \& BRESSON, L.M., 1992. Morphology, genesis and classification of surface crusts in loamy and sandy soils. Geoderma, 55: 225245. 